\title{
Pengaruh Manajemen Konflik Peran Ganda, Pelatihan, Kesehatan dan Keselamatan Kerja Terhadap Perawat Wanita (Studi Kasus di RSUD BLAMBANGAN Banyuwangi)
}

\author{
(The Influence Of Work-Family Conflict Management,Training,Health and Safety On The \\ Performance Of Female Nurses (Case Study at RSUD BLAMBANGAN Banyuwangi))
}

\author{
Althof Sandi Ikmal Huda*, Dewi Prihatini, Hadi Paramu \\ Jurusan Manajemen, Fakultas Ekonomi dan Bisnis, Universitas Jember (UNEJ) \\ Jln. Kalimantan 37, Jember 68121 \\ E-mail: althofsandy93@gmail.com
}

\begin{abstract}
Abstrak
Penelitian ini bertujuan untuk mengetahui dan menganalisis pengaruh manajemen konflik peran ganda, pelatihan, kesehatan dan keselamatan kerja terhadap kinerja perawat wanita di RSUD BLAMBANGAN Banyuwangi. Penelitian ini menggunakan data primer yang diperoleh dari jawaban responden atas kuesioner yang digunakan dalam penelitian. Metode analisis data menggunakan Statistik Deskriptif, Uji Instrumen, Uji Asumsi Klasik dan Uji Hipotesis yang terdiri dari Analisis Regresi Linier Berganda, Uji t, serta Uji F. Hasil Penelitian menunjukkan bahwa manajemen konflik peran ganda, pelatihan, kesehatan dan keselamatan kerja berpengaruh positif dan signifikan terhadap kinerja perawat wanita di RSUD BLAMBANGAN Banyuwangi. Hal ini mengakibatkan semakin baik manajemen konflik peran ganda, pelatiham kesehatan dan keselamatan kerja maka akan meningkatkan kinerja perawat wanita di RSUD BLAMBANGAN Banyuwangi.
\end{abstract}

Kata Kunci: Manajemen Konflik Peran Ganda, Pelatihan, Kesehatan dan Keselamatan Kerja, Kinerja.

\begin{abstract}
This study aims to identify and analyze the influence of work-family conflict management, training, health and safety on the performance of female nurses in RSUD BLAMBANGAN Banyuwangi. This study uses primary data obtained from respondents' answers on the questionnaires used in the study. Method of data analysis using Descriptive Statistics, Instrument Test, Classical Assumption Test and Hypothesis Test consisted of Multiple Linear Regression Analysis, $\mathrm{T}$ test, and F Test. The result of the research shows that the work-family conflict management, training, health and safety have positive and significant influence on the performance of female nurses in RSUD BLAMBANGAN Banyuwangi. This leads to better work-family conflict management, health and safety coach will improve the performance of female nurses at BLAMBANGAN Banyuwangi Hospital.
\end{abstract}

Keywords: Work-Family Conflict Management, Training, Health and Safety, Performance.

\section{Pendahuluan}

Rumah sakit adalah suatu bentuk organisasi yang bergerak dibidang pelayanan jasa kesehatan masyarakat. Rumah sakit sebagai tempat rujukan dari pelayanan kesehatan masyarakat tingkat dasar seperti puskesmas atau pelayanan kesehatan tingkat dasar yang lain perlu untuk menjaga kualitas pelayanan dan fasilitasnya terhadap masyarakat. Perawat merupakan salah satu sumber daya manusia yang memiliki kuantitas paling banyak yang dimiliki sebuah rumah sakit dan didominasi oleh wanita.

Kinerja seorang perawat dalam rumah sakit harus tetap terjaga bahkan harus ditingkatkan hal ini penting karena seorang perawat merupakan tenaga profesional yang memiliki peran penting dalam hubungan komunikasi dengan pasien secara kontinu dan sistematis sehingga dapat disimpulkan bahwa salah satu yang menentukan kualitas sebuah rumah sakit. Beberapa hal yang dapat mempengaruhi kinerja seorang karyawan/ perawat wanita dalam menjalan kan tugasnya adalah konflik peran ganda, pelatihan, kesehatan dan keselamatan kerja.

konflik peran ganda sebagai suatu bentuk konflik antar dimana tekanan-tekanan dari pekerjaan dan keluarga saling tidak cocok satu sama lain (Psichologymania, 2012). Hal ini menunjukan jika dalam menjalankan pekerjaannya sebagai perawat kesadaran keluarga dari seorang perawat kurang untuk memahami dan menerima kondisi pekerjaannya maka hal tersebut dapat menimbulkan konflik bagi diri seorang perawat disaat dia dituntut untuk profesional dalam pekerjaan namun pemahaman dan dukungan keluarga masih kurang, hal tersebut dapat menggangu kegiatan dan kosentrasi seorang perawat wanita dalam bekerja dan dapat menurunkan kinerja.

Manajemen Konflik peran sangat dibutuhkan untuk meminimalisir munculnya konflik peran ganda yang terjadi pada seorang perawat. Dengan demikian seorang perawat khususnya yang berperan ganda dapat mempertahankan kinerja bahkan bisa meningkatkannya walaupun mereka mengalami konflik peran dalam kehidupannya. Manajemen Konflik adalah kegiatan menyusun strategi untuk kemudian dapat diterapkan dalam mengendalikan dan mengatasi konflik dengan cara yang diinginkan (wirawan, 2010).

Hal lain yang mempengaruhi kinerja seorang perawat adalah pelatihan. Menurut (Brotoharsojo ,2003 : 131), Pelatihan atau training bagi para pegawai diberikan oleh perusahaan dalam rangka menjembatani adanya kesenjangan atau gap antara kondisi faktual dari kinerja pegawai terhadap tuntutan ideal

\footnotetext{
* Corresponding author
} 
standard kinerja jabatan yang diduduki oleh pegawai sebagai akibat dari kurangnya pengetahuan, keterampilan serta sikap-sikap kerja tertentu. Pelatihan untuk perawat diberikan sesuai dengan perkembangan dunia kesehatan dan perkembangan alat-alat kesehatan yang bersifat kontinu, perawat harus mengetahui perkembangan ilmu-ilmu kesehatan serta terampil dan cekatan dalam menggunakan atau mengaplikasikan peralatan dan ilmu kesehatan sehingga pasien merasa yakin untuk mendapatkan kesembuhan dari rumah sakit dimana perawat itu bekerja.

Kondisi atau keadaan kesehatan dan keselamatan kerja dalam rumah sakit adalah salah satu hal penting sebagai penunjang kinerja seorang perawat. Rumah sakit adalah tempat kerja yang padat karya, pakar, modal dan teknologi. Namun rumah sakit juga memiliki dampak negatif dan bahaya-bahaya potensial yang di sebabkan oleh faktor biologi (virus,bakteri, jamur, parasit); faktor kimia (antiseptik, reagent, gas anastesi);faktor ergonomi (lingkungan kerja, cara kerja, dan posisi kerja yang salah);faktor fisik (suhu,cahaya,bising, listrik, getaran dan radiasi); faktor psikososial (kerja bergilir, beban kerja, hubungan sesama pekerjaan/atasan). Mangkunegara (2002:163) berpendapat bahwa keselamatan dan kesehatan kerja adalah suatu pemikiran dan upaya untuk menjamin keutuhan dan kesempurnaan baik jasmaniah maupun rohaniah tenaga kerja pada khususnya, dan manusia pada umumnya, hasil karya dan budaya untuk menuju masyarakat adil dan makmur.

Penelitian ini dilakukan di RSUD BLAMBANGAN. RSUD BLAMBANGAN adalah salah satu rumah sakit terbesar yang ada di Banyuwangi. Sebagai salah satu rumah sakit terbesar di Banyuwangi dan rumah sakit rujukan dari pukesmas dan rumah sakit lainnya, RSUD BLAMBANGAN mengakui bahwa beberapa permasalahan dalam RSUD tersebut adalah overload pasien pada beberapa unit pelayanan terutama dibagian rawat inap. Dari segi Sumber Daya Manusia, tenaga medis maupun bagian keperawatan juga masih kurang untuk pelatihan dan diklat sehingga dapat mengganggu dalam pemberian pelayanan yang baik dan bermutu pada pasien. (LAKIP RSUD BLAMBANGAN 2015). Hal ini menandakan bahwa kesiap siagaan yang tinggi untuk siap siaga 24 jam dalm pemenuhan tugas dan kualitas tenaga medis terutama seorang perawat sebagai seorang yang berhubungan langsung dan sering bertemu dengan banyak pasien dibutuhkan agar kinerja dan pelayanan rumah sakit dinilai baik oleh pasien dan keluarga pasien. Karena banyaknya pasien, kondisi kesehatan dan keselamatan seorang perawat harus terjamin karena setiap hari harus berhubungan langsung dengan pasien yang memiliki berbagai macam penyakit dan latar bekalang sosial yang berbeda khususnya seorang perawat wanita yang mungkin lebih rentan dari seorang perwat laki-laki.

Maka dapat dirumuskan permasalahan yaitu, "apakah Manajemen Konflik Peran Ganda, Pelatihan, Kesehatan dan Keselamatan Kerja Berpengaruh terhadap Kinerja Perawat Wanita Di RSUD BLAMBANGAN Banyuwangi?". Adapun tujuan dari penelitian ini adalah untuk mengetahui dan menganalisis pengaruh Manajemen Konflik Peran Ganda, Pelatihan, Kesehatan dan Keselamatan Kerja terhadap Kinerja Perawat Wanita Di RSUD BLAMBANGAN Banyuwangi.

Penelitian ini menggunakan tiga variabel independen yaitu Manajemen Konflik Peran Ganda, Pelatihan, Kesehatan dan
Keselamatan Kerja. Hipotesis yang diajukan dalam penelitian ini adalah :

H1 : Manajemen Konflik Peran Ganda Berpengaruh signifikan secara parsial terhadap Kinerja Perawat Wanita di RSUD BLAMBANGAN Banyuwangi.

H2 : Pelatihan Berpengaruh signifikan secara parsial terhadap Kinerja Perawat Wanita di RSUD BLAMBANGAN Banyuwangi.

H3 : Kesehatan dan Keselamatan kerja Berpengaruh signifikan secara parsial terhadap Kinerja Perawat Wanita di RSUD BLAMBANGAN Banyuwangi.

\section{Metode}

\section{Rancangan Penelitian}

Rancangan penelitian ini diklasifikasikan sebagai explanatory research. Explanatory research yaitu penelitian yang menjelaskan hubungan suatu variabel dengan variabel lain dan menguji keterkaitan antara beberapa variabel melalui pengujian hipotesis .

\section{Populasi dan Sampel}

Populasi penelitian ini adalah seluruh perawat wanita RSUD BLAMBANGAN Banyuwangi yang berjumlah 106 perawat. Sampel Penelitian ini menggunakan tehnik purposive sampling, yaitu peneliti mempunyai pertimabnganpertimbangan tertentu dalam pengambilan responedennya (Arikunto, $2006: 28$ ). pertimbangan tersebut adalah perawat yang telah menikah, terdapat 58 perawat wanita yang memenuhi pertimbangan tersebut.

\section{Jenis dan Sumber Data}

Jenis data yang digunakan dalam penelitian ini adalah data Primer yang diperoleh melalui jawaban kuesioner terkait dengan permasalahan yang diteliti di RSUD BLAMBANGAN Banyuwangi. Data Sekunder yang digunakan dalam penelitian ini adalah berbagai informasi yang penelti dapatkan melalui sumber seperti jurnal, artikel, internet, dan studi pustaka terkait dengan penelitian.

\section{Metode Analisis Data}

Analisis data yang digunakan dalam penelitian ini menggunkan aplikasi SPSS for windows 22. Dengan Uji Kualitas Data, Uji Asumsi Klasik, Uji Regresi Berganda.

\section{Hasil dan Pembahasan}

\section{Data Distribusi Kuesioner}

Kuesioner pada penelitian ini disebarkan di RSUD BLAMBANGAN khususnya di bagian rauangan perawat. Berikut ini adalah tabel dari sebaran kuesioner yang telah disebar.

Tabel 1. Distribusi Kuesioner

\begin{tabular}{lcc}
\hline \multicolumn{1}{c}{ Keterangan } & Jumlah & persentase \\
\hline Kuesioner disebar & 58 & $100 \%$ \\
Kuesioner kembali & 50 & $81 \%$ \\
Kuesioner dioalah & 50 & $81 \%$ \\
Kuesioner tidak memenuhi syarat & 0 & $0 \%$ \\
\hline
\end{tabular}

Sumber : data primer 2016 
Berdasarkan Tabel 1 diatas menunjukkan penyebaran dan tingkat pengembalian kuesioner yang disebar sebanyak 58 lembar dan kembali 50 lembar atau $81 \%$ dan dianggap memenuhi syarat.

\section{Hasil Uji Validitas}

Korelasi antara masing-masing indikator variabel Manajemen Konflik Peran Ganda $\left(\mathrm{X}_{1}\right)$, Pelatihan $\left(\mathrm{X}_{2}\right)$, Kesehatan Dan Keselamatan Kerja $\left(\mathrm{X}_{3}\right)$ dan Kinerja Perawat wanita (Y) menunjukkan bahwa nilai Sig $<0,05$. Hal ini dapat disimpulkan bahwa semua item pertanyaan variabel konflik Peran Ganda $\left(\mathrm{X}_{1}\right)$, Pelatihan $\left(\mathrm{X}_{2}\right)$, esehatan Dan Keselamatan Kerja $\left(\mathrm{X}_{3}\right)$ dan Kinerja Perawat wanita (Y) dinyatakan valid.

\section{Hasil Uji Reliabilitas}

Hasil pengujian reliabilitas pada instrumen variabel Manajemen Konflik Peran Ganda $\left(\mathrm{X}_{1}\right)$ sebesar 0,732, Pelatihan $\left(\mathrm{X}_{2}\right)$ sebesar 0,760, Kesehatan Dan Keselamatan Kerja $\left(\mathrm{X}_{3}\right)$ sebesar 0,742 dan Kinerja Perawat wanita (Y) sebesar 0,751 dengan nilai Cronbach's Alpha atau r alpha diatas 0,60. Dengan demikian dapat disimpulkan bahwa semua variabel yang digunakan dalam penelitian ini reliabel karena $r$ alpha memiliki nilai yang lebih besar dari 0.60 .

\section{Analisis Regresi Linear Berganda}

$$
\begin{aligned}
& \mathbf{Y}=\mathbf{0 , 2 7 6}+\mathbf{0 , 2 4 9} \mathbf{X}_{\mathbf{1}}+\mathbf{0 , 2 8 8} \mathbf{X}_{\mathbf{2}}+\mathbf{0 , 5 4 6} \mathbf{X}_{\mathbf{3}}+\boldsymbol{e} \\
& (0,196)(4,157)^{* * *}(2,429)^{* *}(4,104)^{* * *}
\end{aligned}
$$

f hitung : 56,620 dan $\mathrm{R}^{2}: 0,787$

keteragan: $* * *=$ signifikan pada $\alpha(1 \%=0,01)$, ** $=$ signifikan pada $\alpha(5 \%=0,05)$

Hasil persamaan regresi ini menunjukan bahwa masingmasing variabel bebas yaitu variabel manajemen konflik peran ganda $\left(\mathrm{X}_{1}\right)$, pelatihan $\left(\mathrm{X}_{2}\right)$, kesehatan dan keselamatan kerja $\left(\mathrm{X}_{3}\right)$ berpengaruh signifikan terhadap variabel Kinerja (Y).

\section{Hasil Uji Normalitas}

Hasil uji Normalitas dari variabel-variebel tersebut menunjukkan kurva yang berbentuk simetris dan mendekati sempurna. Nilai dari variabel samping kanan dan kiri berjarak sama terhadap titik tengah yang memiliki frekuensi terbesar. Hal ini menunjukan hasil dari uji normalitas bahwa data terdistribusi dengan normal.

\section{Hasil Uji Multikolinearitas}

Tabel 2. Hasil Uji Multikolinearitas

\begin{tabular}{cccc}
\hline Model & \multicolumn{2}{c}{ Collinearity statistics } & Keterangan \\
\cline { 2 - 3 } X1 & Tolerance & VIF & \\
X2 & 0,788 & 1,286 & $\begin{array}{c}\text { Tidak terjadi } \\
\text { multikolinearitas }\end{array}$ \\
X3 & 0,371 & 2,699 & $\begin{array}{c}\text { Tidak terjadi } \\
\text { multikolinearitas } \\
\text { Tidak terjadi } \\
\text { multikolinearitas }\end{array}$ \\
\hline
\end{tabular}

Sumber: data primer, 2017
Untuk menguji adanya Multikolinearitas dilakukan dengan melihat dari nilai variance inflation factor (VIF) $<10$ dan tolerance $>0,1$. Pada hasil pengujian yang ditunjukkan tabel diatas bahwa masing-masing variebel memiliki $\mathrm{VIF}<10$ dan tolerance $>0,1$ sehingga disimpulkan bahwa tidak terjadi multikolinearitas.

\section{Hasil Uji Heterokedesitas}

Hasil Uji Heteroskesdasdisitas dengan menggunakan scatter plot yaitu titik-titik yang dihasilkan pada gambar tersebut menyebar dan berbentuk tidak beraturan sehingga dapat dikatakan tidak terjadi heteroskesdastisitas.

\section{Hasil Uji T}

Uji $\mathrm{t}$ digunakan untuk mengetahui pengaruh variabel independen $(\mathrm{X})$ terhadap variabel dependen $(\mathrm{Y})$. Kriteria pengujian dengan tingkat signifikansi (a) $=0,05 \%$. jika $\mathrm{t}_{\text {tabel }}>\mathrm{t}_{\text {hitung }}$ Ho diterima, berarti tidak ada pengaruh secara parsial antara variabel independen (X) terhadap variabel dependen $(\mathrm{Y})$ dan jika $\mathrm{t}_{\text {tabel }}<\mathrm{t}_{\text {hitung }}$ Ho ditolak, berarti ada pengaruh secara parsial antara variabel independen (X) terhadap variabel dependen (Y).

Tabel 3. Hasil Uji T

\begin{tabular}{cccc}
\hline Variabel & $\mathbf{t}_{\text {tabel }}$ & $\mathbf{t}_{\text {hitung }}$ & Sig \\
\hline $\mathrm{X} 1$ & 1,675 & 4,157 & 0,000 \\
$\mathrm{X} 2$ & 1,675 & 2,429 & 0,019 \\
$\mathrm{X} 3$ & 1,675 & 4,104 & 0,000 \\
\hline
\end{tabular}

Sumber : data primer, 2017

Berdasarkan tabel diatas dapat diketahi bahwa. variabel Manajemen Manajemen konflik peran ganda $\left(\mathrm{X}_{1}\right)$ memiliki

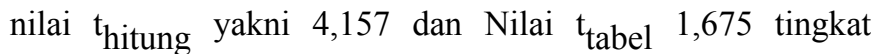
probabilitas $(\alpha)$ adalah 0,000 . Hal ini berarti secara parsial Manajemen Manajemen konflik peran gandaberpengaruh signifikan terhadap Kinerja Perawat Wanita Karena $t_{\text {hitung }}>$

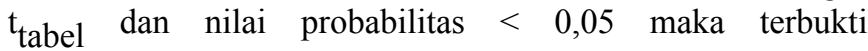
kebenarannya $\left(\mathrm{H}_{1}\right.$ diterima).

Variabel Pelatihan $\left(\mathrm{X}_{2}\right)$ memiliki nilai $\mathrm{t}_{\text {hitung }}$ yakni 2,429 dan Nilai $t_{\text {tabel }} 1,675$ tingkat probabilitas $(\alpha)$ adalah 0,019 . Hal ini berarti secara parsial Pelatihan berpengaruh signifikan terhadap Kinerja Perawat wanita Karena $t_{\text {hitung }}>t_{\text {tabel }}$ dan nilai probabilitas $<0,05$ maka terbukti kebenarannya $\left(\mathrm{H}_{2}\right.$ diterima). variabel Kesehatan Dan Keselamatan Kerja $\left(\mathrm{X}_{3}\right)$ memiliki nilai $t_{\text {hitung }}$ yakni 4,104 dan Nilai $t_{\text {tabel }} 1,675$ tingkat probabilitas $(\alpha)$ adalah 0,000 . Hal ini berarti secara Kesehatan Dan Keselamatan Kerja berpengaruh signifikan terhadap Kinerja Perawat Wanita Karena $t_{\text {hitung }}>t_{\text {tabel }}$ dan nilai probabilitas $<0,05$ maka terbukti kebenarannya $\left(\mathrm{H}_{3}\right.$ diterima).

Hasil Uji F

Tabel 4. Hasil Uji F

\begin{tabular}{ccc}
\hline Variabel & Nilai Annova & Sig. \\
\hline Residual & 56,620 & $0,000^{\mathrm{b}}$ \\
\hline
\end{tabular}

Sumber : data primer, 2017 
Hasil penelitian pada Tabel 3 menunjukan bahwa variabelvariabel ini memilikinilai signifikansi sebesar 0,000 lebih kecil dari 0,05, maka model ini signifikan dan dapat digunakan untuk menguji hipotesis dengan tingkat kepercayaan $95 \%$.

\section{Pembahasan}

\section{Manajemen Konflik Peran Ganda berpengaruh terhadap} Kinerja Perawat Wanita

Hasil analisis regresi berganda pada Uji t terhadap hipotesis pertama $\left(\mathrm{H}_{1}\right)$ menunjukkan bahwa Manajemen Konflik Peran Ganda berpengaruh terhadap Kinerja Perawat wanita dengan melihat taraf signifikansinya yaitu sebesar 0,000 . Hubungan yang ditunjukkan oleh koefisien regresi adalah positif artinya semakin tinggi kemampuan dalam mengelola suatu konflik peran ganda maka Kinerja perawat wanita akan semakin meningkat $\left(\mathrm{H}_{1}\right.$ diterima $)$.

Perawat wanita RSUD BLAMBANGAN tidak merasa kesulitan untuk membagi waktu dan tanggung jawab antara mengurus pekerjaan dan keluarga. Hal tersebut menunjukkan bahwa mereka telah terampil untuk menyelesaikan pekerjaanpekerjaannya tanpa terganggu oleh kepentingan keluarga, sehingga kinerja dapat meningkat karena mereka tidak mencampuradukkan permasalahan / kepentingan keluarga terhadap pekerjaan dan begitu juga sebaliknya.

Hasil penelitian ini sejalan dengan penelitian sebelumnya yang dilakukan oleh Daine T. (2014) di Bank "x" Kabupaten Jember yang menyatakan bahwa terdapat pengaruh yang signifikan dari Manajemen Konflik Peran Ganda terhadap Kinerja karyawan. Jadi dapat disimpulkan Manajemen Konflik Peran Ganda berpengaruh terhadap Kinerja Perawat wanita.

\section{Pelatihan berpengaruh terhadap Kinerja Perawat wanita}

Hasil analisis regresi berganda pada Uji t terhadap hipotesis kedua $\left(\mathrm{H}_{2}\right)$ menunjukkan bahwa Pelatihan berpengaruh terhadap Kinerja Perawat wanita dengan melihat taraf signifikansinya yaitu sebesar 0,019. Hubungan yang ditunjukkan oleh koefisien regresi adalah positif artinya semakin tinggi Pelatihan maka Kinerja Perawat wanita akan semakin meningkat $\left(\mathrm{H}_{2}\right.$ diterima $)$.

Perawat wanita di RSUD BLAMBANGAN telah mendapatkan pelatihan yang diberikan oleh rumah sakit dan mengikuti pelatihan tersebut dengan baik. Antusias para perawat yang tinggi untuk mengikuti pelatihan tersebut menunjukan bahwa mereka ingin memberikan kontribusi yang baik untuk rumah sakit sehingga tujuan rumah sakit tercapai. Mereka juga telah mampu menyerap dan kemudian mengaplikasikan hasil dari pelatihan tersebut kedalam pekerjaannya hal ini mencerminkan bahwa pelatihan yang diberikan oleh rumah sakit berpengaruh dan dapat meningkatkan kinerja perawat tersebut.

Hasil penelitian ini sejalan dengan penelitian sebelumnya yang dilakukan oleh Ninin Non Ayu S (2013) pada PT. Muba Electric Power, Sekayu yang menyatakan bahwa terdapat pengaruh yang signifikan dari Pelatihan terhadap Kinerja Perawat wanita. Jadi dapat disimpulkan Pelatihan berpengaruh terhadap Kinerja Perawat wanita.

\section{Kesehatan dan Keselamatan Kerja berpengaruh terhadap Kinerja Perawat Wanita}

Hasil analisis regresi berganda pada Uji t terhadap hipotesis ketiga $\left(\mathrm{H}_{3}\right)$ menunjukkan bahwa Kesehatan Dan Keselamatan Kerja berpengaruh terhadap Kinerja Perawat wanita dengan melihat taraf signifikansinya yaitu sebesar 0,000 . Hubungan yang ditunjukkan oleh koefisien regresi adalah positif artinya semakin tinggi Kesehatan Dan Keselamatan Kerja maka Kinerja Perawat wanita akan semakin meningkat $\left(\mathrm{H}_{3}\right.$ diterima).

Pihak rumah sakit telah memperhatikan kondisi kesehatan dan keselamatan para perawat di RSUD BLAMBANGAN. Pemberian jaminan kesehatan oleh rumah sakit telah membantu meningkatkan kinerja seorang perawat karena mereka telah merasa terjamin dalam pekerjaannya. Ketersediaan peralatan medis yang memadahi dan sesuai standart serta alat-alat kesehatan untuk menjaga dan melindungi para perawat telah tersedia. Sehingga para perawat dengan tenang dan nyaman dalam melaksanakan pekerjaannya yang dapat berimbas pada peningkatan kinerja perawat.

Hasil penelitian ini sejalan dengan penelitian sebelumnya yang dilakukan oleh Ryska Rahman. (2013) pada PT. Ceria Utama Abadi, Palembang yang menyatakan bahwa terdapat pengaruh yang signifikan dari Kesehatan Dan Keselamatan Kerja terhadap Kinerja Perawat wanita jadi dapat disimpulkan Kesehatan Dan Keselamatan Kerja berpengaruh terhadap Kinerja Perawat wanita.

\section{Simpulan}

Berdasarkan hasil analisis dan pembahsan yang telah peneliti jelaskan maka dapat disimpulkan sebagai berikut :

Manajemen Konflik Peran Ganda berpangaruh signifikan secara parsial terhadap Kinerja Perawat Wanita di RSUD BLAMBANGAN Kabupaten Banyuwangi

Pelatihan berpengaruh signifikan secara parsial terhadap Kinerja Perawat wanita di RSUD BLAMBANGAN Kabupaten Banyuwangi.

Kesehatan Dan Keselamatan Kerja berpengaruh signifikan secara parsial terhadap Kinerja Perawat wanita di RSUD BLAMBANGAN Kabupaten Banyuwangi.

Keterbatasan dalam penelitian ini adalah Pengambilan data melalui kuisioner masih menggunakan kertas / paperless sehingga biaya yang dikerluakan semakin banyak. pengabaian mengenai ruangan-ruangan kerja yang tingkat kesibukan kerja berbeda, sehingga berpengaruh pula pada tingkat konflik dalam dualisme peran seorang perawat wanita yang berada di RSUD Blambangan tersebut. mengenai variabel bebas yang di gunakan hanya terdiri dari tiga variabel untuk mengetahui sberapa besar pengaruhya terhadap kinerja perawat wanita di RSUD Blambangan. Sehingga untuk penelitian selanjutnya perlu melengkapai dengan variabel lain seperti stress kerja, kecerdasan emosional dan tekanan kerja untuk mengetahui lebih dalam bagaiamana pengaruhnya terhadap kinerja perawat wanita RSUD Blambangan. 


\section{Referensi}

Arikunto, Suharsimi. 2006. Prosedur Penelitian Suatu PendekatanPraktif. Jakarta : Rineka Cipta

Mangkunegara, DR A.A Anwar Prabu. 2005. Evaluasi Kinerja SDM. Bandung: Penerbit Refika Aditama

Psichologymania.2012.pcychologymania.com/2012/10/pengertianko nflikperanganda.html

Rahman, Ryska. 2013. Pengaruh Keselamatan dan Kesehatan Kerja terhadap Kinerja Karyawan PT. Ceria Utama Abadi Palembang. Skripsi. Universitas Sriwijaya
RSUD Blambangan 2015. Laporan Akuntabilitas Kinerja Instansi Pemerintah RSUD Blambangan Banyuwangi. Rsudbw.banyuwangi.go.id

Salmah, Ninin Non Ayu. 2012. Pengaruh Program Pelatihan dan Pengembangan Karyawan terhadap Kompetensi pada PT. Muba Electric Power Sekayu. Skripsi. Universitas PGRI Palembang.

Taufariska, daine. 2015. Pengaruh Konflik Peran Ganda, Kecerdasan Emosional dan Komitmen Organisasi Terhadap Kinerja Karyawati Pada PT. Bank "x" Cabang Jember . tidak dipublikasikan. Skripsi. Unversitas Jember.

Wirawan. 2010. Konflik dan Manajemen Konflik : teori, Aplikasi, dan Penelitan. Jakarta : Salemba Empat

Wungu, Jiwo \& Hartanto Brotoharsojo. 2003. Merit System. Jakarta : PT. RajaGrafindo Persada. 